\title{
EARLY DEVELOPMENT OF TRANSPLANTED ISIDIOID SOREDIA OF LOBARIA PULMONARIA IN AN ENDANGERED POPULATION
}

\author{
C. SCHEIDEGGER*
}

\begin{abstract}
Vegetative diaspores of Lobaria pulmonaria were transplanted to previously uncolonized trees. The early development of the corticated but otherwise non-stratified isidioid soredia was studied mainly by low-temperature scanning electron microscopy. Anchoring hyphae developed from cortical hyphae after 2-4 months and later apical or lateral pseudomeristematic growth zones were formed. After 15 months the growth zones further differentiated into $0.5-\mathrm{mm}$-broad lobes and revealed a stratified thallus typical for this foliose epiphytic lichen species. The experiment showed that the small population size of $L$. pulmonaria was limited by the low reproductive potential of the species and that it might fail to compensate for a relatively high disturbance, natural or anthropogenic, in the stand.
\end{abstract}

C 1995 The British Lichen Society

\section{Introduction}

Lichenized ascomycetes have evolved an impressive range of symbiotic and aposymbiotic propagules (Poelt 1993, 1994; Büdel \& Scheidegger 1995) that are adapted to different ecological (Rogers 1990; During 1992) and reproductive (Bowler \& Rundel 1975) strategies. After dispersal to a new habitat (Bailey 1976), fixation, germination and subsequent juvenile development (van der Pijl 1982) are essential steps for successful reproduction. These are all influenced by ecological parameters and anthropogenic disturbance.

Lobaria pulmonaria has the potential for two divergent strategies of reproduction (Bowler \& Rundel 1975), i.e. sexual, through ascospore ejection, and vegetative, by the production of symbiotic propagules. However, fertile specimens are found only in luxuriant populations, for example on the northern slope of the Swiss Alps. Also, Jordan (1973) reported that, although about $15 \%$ of the North American specimens studied are fertile, apothecia are often non-functional. Furthermore, Wirth (1987) and Hallingbäck \& Martinsson (1987) state that fertile thalli have completely disappeared in Baden-Württemberg (Germany) and in the district of Gäsene (SW Sweden) although they were reported repeatedly in former times.

Actual populations of $L$. pulmonaria in managed forests are often very small, sometimes restricted to only a few trees. In the study area of the Swiss Plateau, fertile specimens are currently absent but were collected by Siegfried and Fischer-Siegwart in 1881 and 1877, respectively. Dispersal by aposymbiotic ascospores may therefore only contribute to the dispersal of luxuriant populations and may play a more limited role in the reproduction of small and

^Swiss Federal Institute for Forest, Snow and Landscape Research, CH-8903 Birmensdorf, Switzerland. 
endangered populations. However, soredia and isidioid soredia are regularly formed in small populations and on small thalli and therefore play the major role in dispersal.

Although L. pulmonaria is a widespread foliose lichen, distributed over parts of Europe, Asia, Africa and North America (Yoshimura 1971), this species has suffered a considerable decline since the last century, as reported from various parts of central and northern Europe (see Hallingbäck \& Martinsson 1987). Because L. pulmonaria is sensitive to acidic air pollution and ozone (Sigal \& Johnston 1986; Scheidegger \& Schroeter 1995), air pollution may regionally be a major cause for the decline in Lobaria populations. Furthermore, $L$. pulmonaria has been found to be dependent on a high ecological continuity of its habitats and the longevity of its phorophytes (Rose 1976). Gauslaa (1985) reported that L. pulmonaria in south-west Norway requires a combination of a bark $\mathrm{pH}>5$ together with a high longevity of the substratum. Even slightly intensified agricultural or forestry management may contribute to the extinction of L. pulmonaria and other lichen species (Rose 1992; Wirth 1976).

The dependence of $L$. pulmonaria on undisturbed sites is related to the ecological and reproductive strategies of the adult and also the ecological requirements of the juvenile thalli. Experiments where adult thalli or vegetative diaspores are transplanted may therefore help to explain the decline in existing populations.

In the case of foliose and fruticose lichens, early development of lichen diaspores involves a cascade of morphogenetic processes leading to a highly differentiated vegetative thallus. The resynthesis and early development of lichen thalli from aposymbiotic propagules have been mainly investigated under laboratory conditions, as recently reviewed by Ahmadjian (1990, 1993). Only Ott $(1987 a, b)$ and Garty \& Delarea (1988) have described the development of non-lichenized, generative diaspores of Xanthoria parietina, Lecanora dispersa, Protoblastenia immersa, Candelariella aurella and Caloplaca aurantia under field conditions. The fixation, germination and establishment of symbiotic propagules have been described for various foliose and fruticose species (Schuster et al. 1985; Jahns 1988). Both sorediate species (Schuster 1985; Ott 1987c) and the isidiate Parmelia saxatilis disintegrate and form a basal tissue (Jahns 1984) that has a considerably different organization than have the diaspores directly after dispersal. However, in $P$. pastillifera, the knob-like isidia keep their internal structure. They are attached to the substratum by their former upper, now lower, surface. Rhizinae are then formed, raising the developing diaspore above the substratum. Subsequently pseudomeristematic zones of the isidium development into the first lobules (Honegger 1987).

Lobaria pulmonaria or other related species have hitherto been transplanted in various experiments. Denison (1988) described a culturing technique on nylon monofilaments for the measurement of growth rates in the field. Hawksworth and Rose (Hawksworth 1971) transplanted adult thalli to test whether $L$. pulmonaria would be able to tolerate the microclimate at various study sites. Hallingbäck (1990) rubbed soredia-containing thalli of L. pulmonaria on the rough bark of Acer platanoides into about $1-\mathrm{mm}$-sized fragments. After 18 months he obtained thalli $10-20 \mathrm{~mm}$ in size; however, the development of the fragments was not described in further detail. 
Because L. pulmonaria is a highly endangered species on the Swiss Central Plateau (Scheidegger et al. 1991a) and elsewhere in Europe, I was interested to discover whether the reproductive strategies of this species were limiting the population size at disturbed sites and whether, using artificial propagation of naturally produced vegetative diaspores, threatened populations of $L$. pulmonaria could eventually be increased in terms of number of individuals and phorophytes colonized by the species.

\section{Materials and Methods}

The vegetative diaspores of $L$. pulmonaria were collected from one lobe of a non-fertile but otherwise luxuriant thallus growing on a 60-70-year-old Fraxinus excelsior in a Melico-Fagetum in the commune of Rothrist (canton of Aargau, Switzerland). Granular soredia were produced in punctiform laminal soralia (Fig. 1) and further developed into corticated isidioid soredia (Fig. 2). The cylindrical diaspores were removed from the thallus with a wet paint-brush, transferred in a petri dish containing distilled water and transplanted onto the discs within $30 \mathrm{~min}$. The donor thalli were not damaged by this procedure as this was checked macroscopically and, after 2 years, by chlorophyll fluorescence (Scheidegger unpublished work).

Discs ( $8 \mathrm{~mm}$ in diameter) of two layers of surgical gauze (Flawa, Schafthausen, Switzerland) were mounted with staples (STCR 2115-1/4 in. Alum, Stanley Bostich, France) on the bark or on mats of epiphytic bryophytes (Figs 3-5) of trees exceeding a stem diameter of $30 \mathrm{~cm}$. Lobaria pulmonaria was absent on the trees selected for the experiment. Controls (discs without diaspores) showed no natural spontaneous development of $L$. pulmonaria. Discs of bark from Fraxinus having narrow natural cracks were excised from recently cut trees. Additional cracks were cut in the bark surface. These discs were dried and stored air-dry until they were glued with Rilacol SLB 3 (Farbo, Schönenwerd, Switzerland) on the bark of the acceptor tree. Acceptor trees were selected according to my field knowledge of potential habitats of $L$. pulmonaria. Thus, 30 discs of each substratum were mounted on homogeneous parts of the stem, directly on the bark or on the upper limits of thin mats of pleurocarpous bryophytes. Diaspores were transferred onto the fixed artificial substratum either with a pipette in a droplet of water or with a wet paint-brush. Using a hand lens I tried to place single diaspores within the meshes of the surgical gauze or within the natural or artificial cracks of the bark discs. After $2,4,6,8,10,12$, and 15 months one or two randomly selected discs were harvested for further investigation by scanning electron microscopy (SEM). The other discs were photographed with a macro-lens equipped with a ring flash at the same intervals and later irregularly for 3 years.

For fine structural investigations in the low-temperature scanning electron microscope (LTSEM) (see Echlin 1992; Scheidegger 1994), discs were hydrated in the laboratory with distilled water for $10 \mathrm{~min}$, then carefully blotted to remove surface water and mounted with double-sided self-adhesive paper (Fotofix, Herma, Germany) on aluminium stubs. Specimens on the aluminium stubs were immediately frozen in liquid nitrogen $\left(\mathrm{LN}_{2}\right)$ and stored in $\mathrm{LN}_{2}$ until further treatment. The specimens were transferred to the cold stage in the preparation chamber of a SCU 020 scanning cryopreparation unit (Bal-Tec, Principality of Liechtenstein) (Müller $e t$ al. 1991; Scheidegger et al. $1991 \mathrm{~b}$ ) and partially freeze-dried for $10 \mathrm{~min}$ at $-80^{\circ} \mathrm{C}$ in a high vacuum $\left(\mathrm{P}<2 \times 10^{-4} \mathrm{~Pa}\right)$. Platinum sputter-coating was then carried out after raising the pressure to $2 \cdot 2$ $\mathrm{Pa}$. The coating thickness was $15 \mathrm{~nm}$, measured by a quartz thin film monitor. After coating, the specimens were transferred with a manipulator through the sliding vacuum valve onto the SEM cold stage of a SEM 515 (Phillips, The Netherlands). In order to avoid excessive charging of the cotton fibres of the gauze under the electron beam of the SEM, it was important to wet the samples prior to cryofixation. Only with a relatively high amount of capillary water can chemically untreated gauze be investigated at $12 \mathrm{kV}$ accelerating voltage without charging. After LTSEM observations the specimens can be further processed for supplementary light microscopy and cut together with the substratum to study diaspore-substratum contacts.

After LTSEM investigation, specimens were thawed and chemically fixed in $6 \%$ formaldehyde in phosphate buffer at $\mathrm{pH} 7 \cdot 2$. Parts of the discs with diaspores were excised, dehydrated in a series of ethanol and embedded in glycol-methacrylate. The specimens consisting of diaspores and cotton gauze were sectioned with glass knives $(1.5 \mu \mathrm{m})$ and stained with Giemsa for 

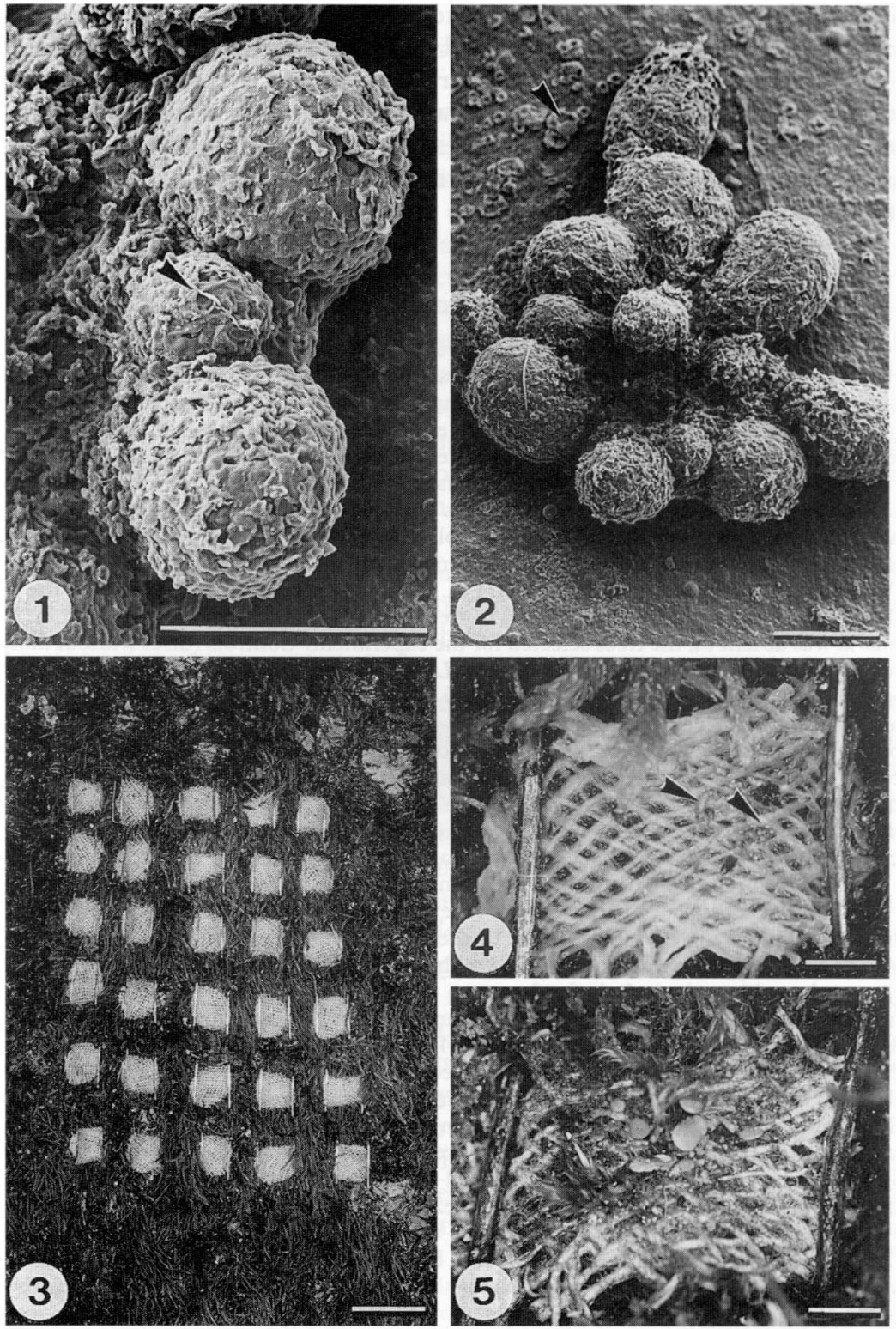

FIgs. 1-2. Low-temperature scanning electron micrography of propagules. Fig. 1. Early development of vegetative propagules on the thallus. The early stages were globular and with a rough surface, consisting of clearly distinguishable collapsed hyphae (arrowhead). FIG. 2. Isidioid soredia developing in a laminal soralium. After the formation of globular structures, further development led to corticate, cylindrical diaspores called isidioid soredia. Note pruina on the thallus surface (arrowhead) but not on the propagules. FIGS 3-5. Field appearance of experimental site and diaspores. FIG. 3. Experimental site on a moss-covered stem of Fraxinus with 30 discs of surgical gauze mounted on the bark with staples. FIg. 4. Disc with diaspores (arrowheads) 2 months after transplantation. Globular and cylindrical isidioid soredia were put mainly between the threads of the artificial substratum. FIG. 5. Same disc as in Fig 4, 24 months after transplantation. Some diaspores had dropped but many had developed into small lobes. Scales:

Figs 1, 2=0.1 mm; Fig. 3=2 cm; Figs 4, 5=1 mm. 


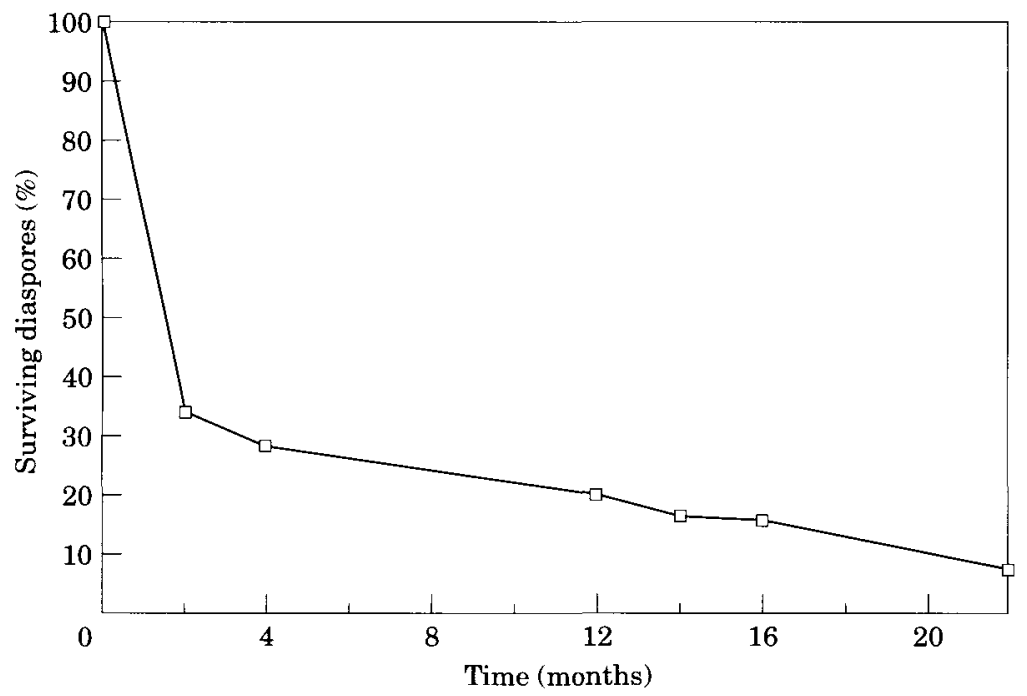

FIG. 6. Percentage of surviving diaspores on the substratum ( 2 discs). A high percentage of diaspores were lost during the first 2 months. After diaspores developed anchoring hyphac, diaspore loss was considerably reduced.

chitinaceous material (Clark 1981). Old records of $L$. pulmonaria were studied at the herbarium of the Botanical Institute Zürich.

\section{Results}

After transplantation, 30-70 granular or cylindrical isidioid soredia were identified on each disc of the artificial substrata. If the diaspores were sown in the dry state or if diaspores in water were dropped on the substratum without further placement, almost all diaspores were lost during the first 2 months. However, even if the microtransplants were carefully placed between the fibres of the gauze or within natural or artificial cracks of the bark, about $60 \%$ of the diaspores were lost (Figs 4, 6, 7) and a few diaspores were shifted downwards on the substratum (Fig. 7), probably by water run-off. This considerable loss occurred on both bark and surgical gauze. Parts of the diaspores were probably lost due to herbivore activity, indicated by droppings of arthropods and snails lying on the discs. Others dropped from the substrata due to hygroscopic movements of the diaspores and the substratum during natural desiccation and rewetting processes. However, after 2 months, about $20 \%$ of the remaining diaspores had developed a few anchoring hyphae growing out of the cortex of the diaspore (Fig. 11, 12), fixing them to the substratum. No differences were found to occur between diaspores developing on gauze (Fig. 11) and bark (Fig. 12).

After 4 months the additional loss of propagules was only minor (Figs. 6, 8-10) and the majority of the diaspores had developed numerous confluent anchoring hyphae, which formed broad, fan-shaped contact zones to the substratum (Figs. 13, 14). These hyphae produced an extracellular, gelatinous 


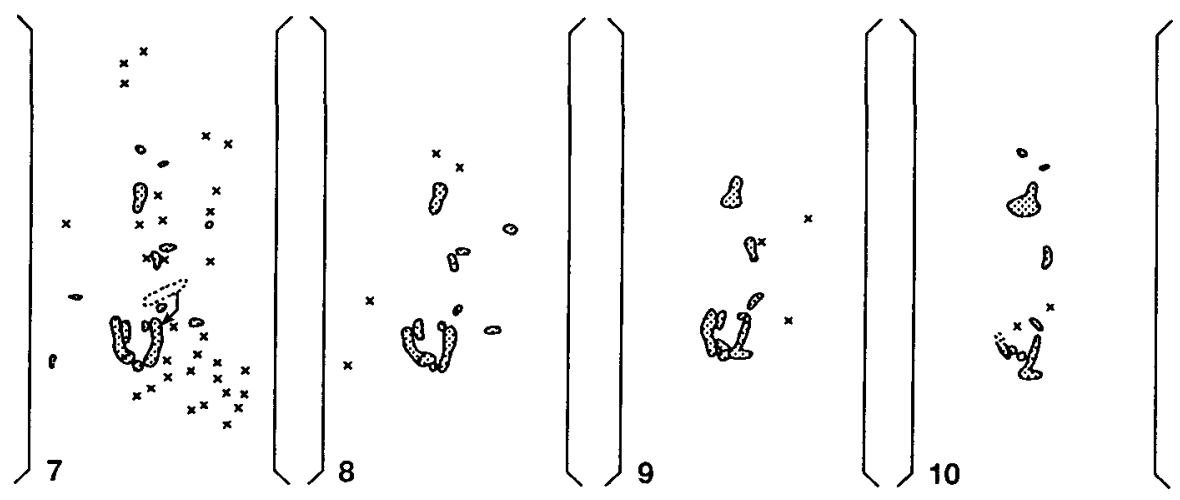

FIG. 7-10. Macroscopic observations of microtransplants over 22 months. The diaspores are redrawn from macrophotographs. The two vertical lines indicate staples fixing the surgical gauze; dotted areas indicate the shape of the developing diaspores; $\mathrm{X}$ indicates a diaspore lost since the last observation. Fig. 7.2 months after transplantation. One diaspore shifted slightly downwards as indicated by the arrow. About $65 \%$ of the diaspores were lost since the start of the experiment. FIG. 8. 4 months after transplantation. Only a few additional diaspores were lost. FIG. 9. 14 months after transplantation. Two diaspores developed spathulate lobules at their lower apex.

FIG. 10. 22 months after transplantation. Note accelerated growth of the developing lobules.

matrix around the hyphae and the contact zone to the substratum sometimes became brownish. Detailed SEM observations of the diaspore-substratum contact was only possible on gauze. On bark, no superficial hyphae were found, probably because of the considerably higher porosity of this substratum. However, when diaspores directly contacted pleurocarpous mosses such as Hypnum cupressiforme, superficial hyphae were regularly found on decaying leaves (not shown).

During juvenile development a considerable percentage of diaspores were usually damaged due to herbivore activity or by overgrowing bryophytes. Figure 16 shows a diaspore partially damaged by a mite. A considerable part of the cortex and the photobiont-containing inner plectenchyma had been destroyed. The heavily collapsed abdomen of the mite indicates that the mite died before the diaspore was collected in the field and cryofixed soon after. Meanwhile the diaspore started regeneration, as indicated by the growing hyphae (Fig. 17). Fungal hyphae with apical dominance showed predominantly vertical growth and the hyphae were tending to grow over the legs of the predator. Apical parts of the diaspore that were not damaged would probably have developed further.

Cylindrical isidioid soredia were covered with a thin, smooth epicortical layer. It was produced by the cortical hyphae and stained intensively with Giemsa (Figs 19-21). It was restricted to the two outermost layers of the cortex and completely surrounded the diaspores irrespective of their upper or lower side. However, at the base of the developing parts of diaspores the epicortical layer was often disintegrating (Figs 14, 16). The propagules were corticated but otherwise non-stratified (Fig. 21).

Cortical hyphae adjacent to the substratum formed outgrowing hyphae 2-4 months after transplantation (Fig. 19). Usually bundles of conglutinated 

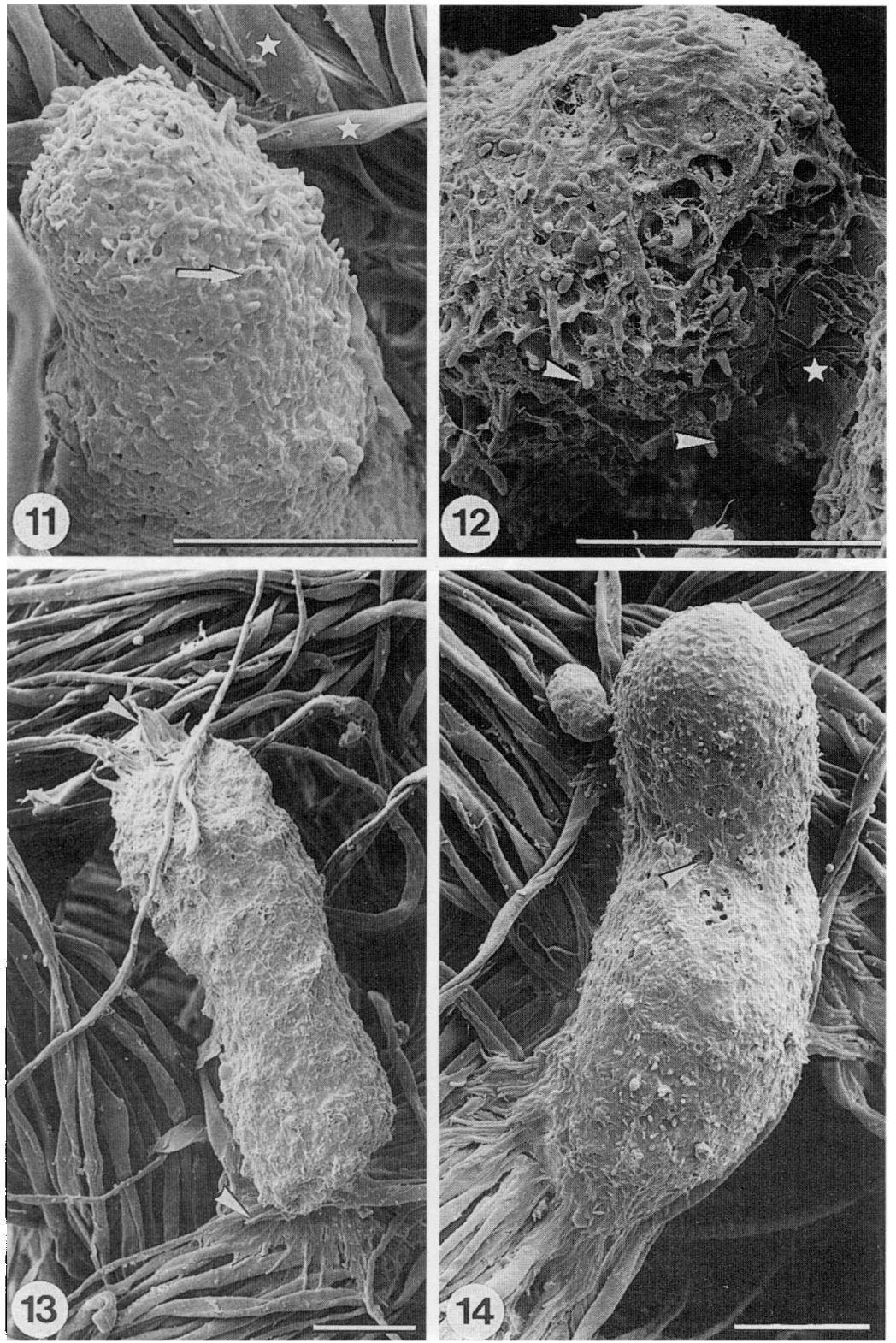

FIGS. 11-14. Low-temperature scanning electron micrographs of diaspores 2 and 4 months after transplantation. FIG. 11. Diaspore growing on surgical gauze 2 months after transplantation. Short hyphae (arrow) are growing out of the cortex. Note cotton fibres of the substratum (asterisk). FIG. 12. Diaspores growing in artificial notches of a bark disc (Fraxinus excelsior) 2 months after transplantation. Short hyphae (arrowheads) are growing out of the cortex. Substratum and diaspore-substratum contacts are covered with a thin water film (asterisk). FIG. 13. Diaspore growing on gauze 4 months after transplantation. Anchoring hyphae (arrowheads) are formed where the diaspore is in close contact to the substratum. FIG. 14. Diaspore growing on gauze 4 months after transplantation. About $50-\mu \mathrm{m}$-long hyphae have developed from different parts of the diaspore. The diaspore is covered with a smooth epicortical layer disintegrated at the base of the developing apical part of the diaspore (arrowhead). Scale $=0.1 \mathrm{~mm}$. 

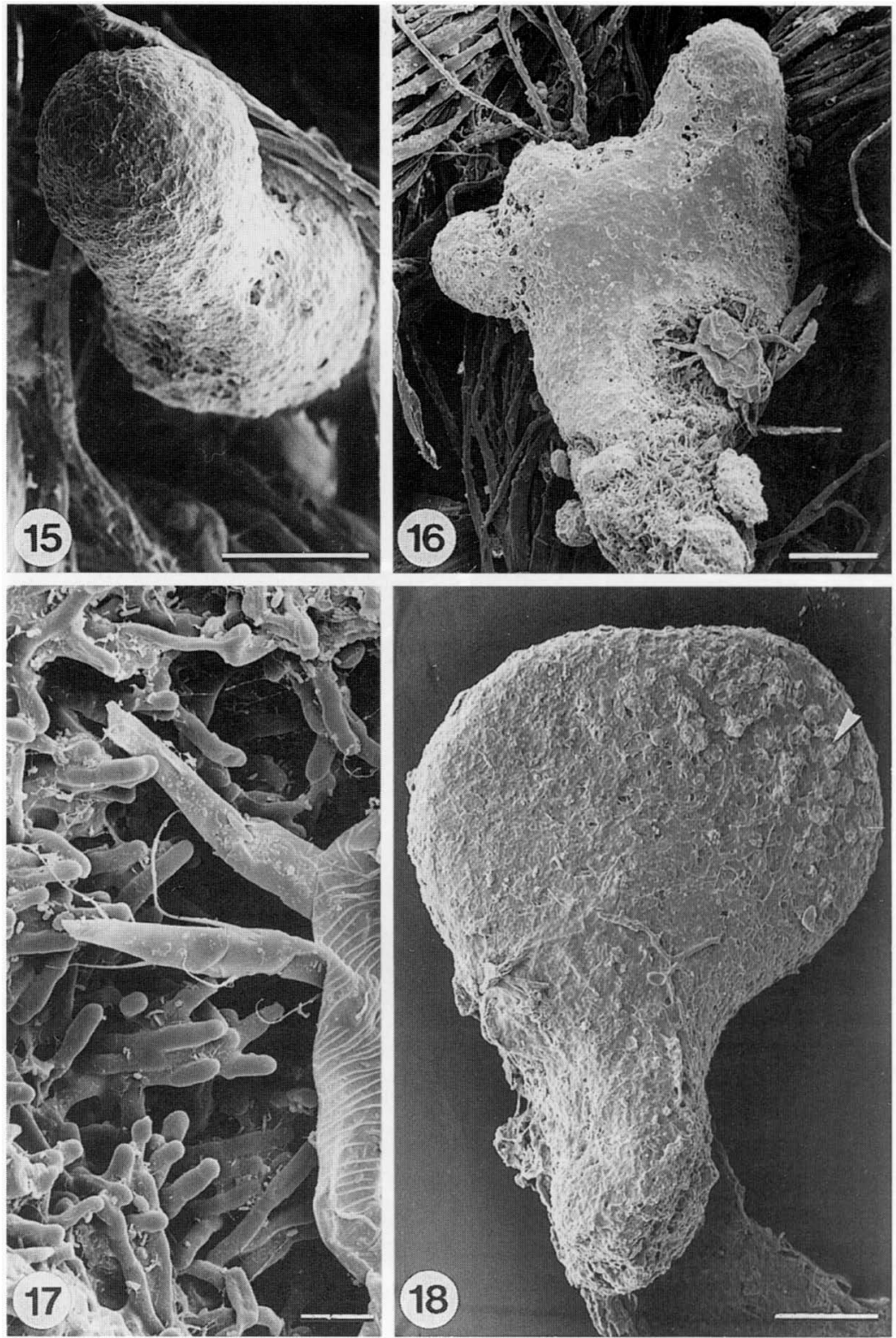

FIGs. 15-18. Low temperature scanning electron microscopy micrographs of diaspores growing on gauze 6 to 15 months after transplantation. FIG. 15. Diaspore 12 months after transplantation. A relatively long apical part has developed out of a diaspore. The pseudomeristematic zone has become spathulate. FIG. 16. Diaspore 6 months after transplantation. Apical and lateral growth zones have formed. The epicortical layer has disintegrated at the base of the pseudomeristematic zones. An arthropod had destroyed a part of the cortex, but it died before the diaspore was harvested in the field. FIG. 17. Detail of Fig. 16 showing regeneration of the destroyed lichen cortex. Fungal hyphae were growing intensively perpendicular to the diaspore surface and overgrowing a leg of the arthropod. FIG. 18. Diaspore 15 months after transplantation. An obovate lobule developed out of the cylindrical diaspore. The diaspore was removed from the artificial substrate prior to cryo-fixation. Note pruina at the margin of the lobule (arrowhead). Scale $=0.1 \mathrm{~mm}$. 

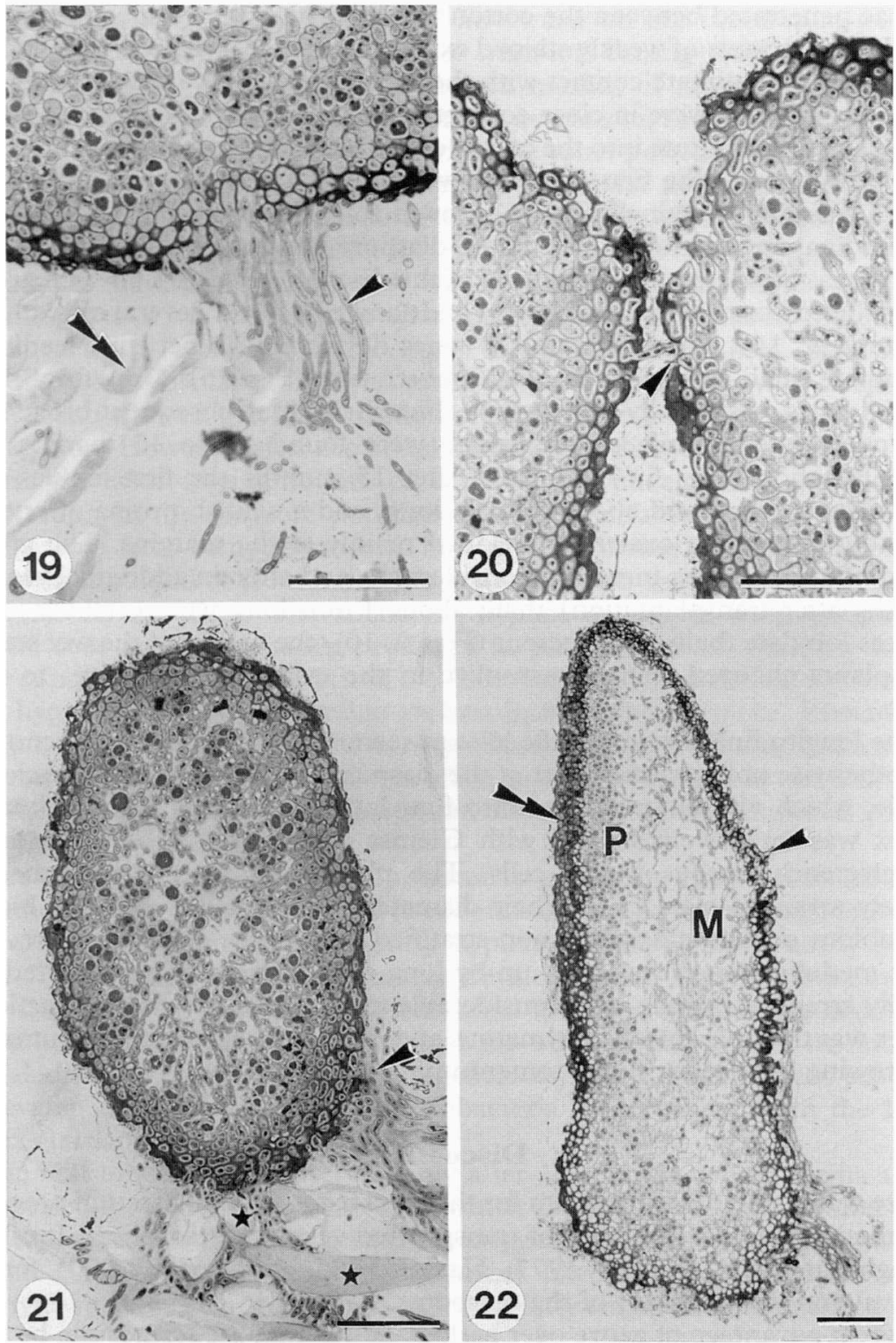

FIGs. 19-22. Light micrographs of transplanted diaspores developing on gauze. Fig. 19. Diaspore 4 months after transplantation. Anchoring hyphae (arrowhead) were growing out of the cortical cells and penetrating between the cotton fibres of the artificial substratum (double arrowhead). FIG. 20. Two diaspores in close contact, 4 months after transplantation. Outgrowing cortical hyphae could penetrate into the neighbouring diaspore (arrowhead). FIG. 21. Diaspore 4 months after transplantation. Anchoring hyphae produced high amounts of extracellular matrix (arrowhead) and penetrated between the fibres of the artificial substratum (asterisk). FIG. 22. Diaspore 15 months after transplantation; same individual as in Fig. 18. The lower, cylindrical part of the transplant is corticate but otherwise non-stratified. Note the oversized photobiont cells in this part. The upper part, being a section of the obovate lobe is stratified into an upper cortex (double arrowhead), photobiont layer (P), medulla $(M)$ and lower cortex with tomentum (arrowhead). Scale $=0 \cdot 1 \mathrm{~mm}$ 
hyphae penetrated between the cotton fibres of the artificial substratum (Fig. 21). High amounts of weakly stained extracellular matrix are secreted and had established an intimate contact with the substratum (Figs 19, 21). When two or more diaspores were in close contact during early development, anchoring hyphae could penetrate into the cortex of the neighbouring diaspore (Fig. 20).

After 6 months, the first diaspores were found where one or several apical (Fig. 14) and/or marginal (Fig. 16) growth zones had developed. They led to longitudinal and lateral growth of the diaspore and to knob-like structures if growth was restricted to a small part of the diaspore (Fig. 16). In such growth zones the epicortex was decomposed and showed holes of several micrometres in size (Fig. 14). The meristematic zones developed further, first leading to spathulate thalli ascending from the substratum (Fig. 15). Growth of newly formed parts was usually downwards (Figs 5, 7-10). Subsequent broadening led to obovate juvenile stages, which were found 12 to 15 months after transplantation (Figs 5, 7-10,18). After 15 months the first lobules were $0.3-0.5 \mathrm{~mm}$ broad and about $0.5 \mathrm{~mm}$ long, and a whitish pruina of crystals, probably of calcium oxalate, developed mainly at the margins. The growth rate of the lobule then increased considerably, and after an additional year (30 months after transplantation) thalli about $1 \mathrm{~mm}$ long were established. As soon as lobulate thalli were present (Figs 9, 10), the colour of the wet state of transplants changed from brown-olive in the cylindrical diaspores to vivid green.

The longitudinal section of the lobe as seen in Fig. 18 showed the corticate but otherwise non-stratified part of the diaspore and the stratified, developing lobule, which was differentiated into four layers (Fig. 22). The thick upper cortex was intensively stained with Giemsa and consisted of thick-walled, paraplectenchymatous fungal cells. The photobiont layer was formed by densely arranged algal cells. Their diameters were smaller than the biggest photobiont cells found in the non-stratified part of the same diaspore. The thick medullary layer was built up by long-celled, irregularly orientated and loosely arranged hyphae with considerable intercellular air spaces. The lower cortex was thin, paraplectenchymatous and it stained with Giemsa. Numerous outgrowing hyphae formed a tomentum.

\section{Discussion}

Gauze was a suitable substratum for the investigation of the fixation processes and the juvenile development of transplanted vegetative diaspores. It offered enough safe sites (Harper 1977; Naylor 1985; Armstrong 1990) for the survival and development of the diaspores.

A great advantage of gauze over bark discs was that the former can be fixed on the phorophyte and carefully integrated into the fine topography of the stem without changing substrate chemistry and water run-off. Furthermore, they can be carefully integrated into the existing bryophyte or lichen cover. This is important for future studies on the influence of competition on the early development and establishment of microtransplants. The time needed for the development of differentiated lobules from diaspores did not differ between the gauze substratum and the bark. 
If sown in the dry state or dropped into water on the substratum without further placement, almost all diaspores were lost during the first 2 months. Also if the diaspores were placed between meshes of the surgical gauze or within artificially cut or naturally occurring notches on the bark substratum, a considerable percentage were lost during the same period. These results are comparable with findings by Armstrong (1990), who described survivorship curves in relation to substratum surface characteristics of experimentally sown soredia of Hypogymnia physodes.

A high loss during the first period was not surprising because the surface of the diaspores of $L$. pulmonaria was smooth, and no viscous material as described from $P$. pastillifera (Honegger 1987) was found in L. pulmonaria. The amount of lost diaspores was equally high on bark discs with deeply cut notches and showed that early fixation of diaspores is a very crucial period for propagation. However, after the first 4 months, the diaspores were fixed to the substratum with high amounts of anchoring hyphae, which paralleled a stabilization of the diaspore population on the surfaces studied. Later loss mainly arose from competition with bryophytes growing through the fibres of the substratum and/or from herbivore activity, which sometimes destroyed all diaspores on the discs. The anchoring hyphae developed from outgrowing cortical cells and were mainly produced in parts where the diaspore was in close contact with the substratum. No differences in the potential for forming such hyphae were found between various parts of the diaspore. Remarkably high amounts of fungal material were produced for the anchoring hyphae that penetrated between the cotton fibres of the gauze substratum. It was estimated that the biomass of these non-lichenized anchoring hyphae exceeded $20 \%$ of the volume of the diaspore.

The bodies of the diaspores only started to germinate after 4-6 months and then they mostly developed apical pseudomeristems. Such growing zones rose above the substratum; no anchoring hyphae developed from newly grown parts. These pseudomeristems further developed into stratified lobules that were differentiated into upper cortex, algal and medullary layer, and lower cortex with tomentum, as was typical for adult thalli. So far no internal cephalodia have been found on the regenerates, but these have been reported to develop on adult thalli from cyanobacteria incorporated from the lower cortex (Jordan 1970).

The first lobules were observed only after 12 months, which seems a very long period for a fast-growing species, which can naturally reach around $1 \mathrm{~cm}$ per year linear growth in this area (Scheidegger unpublished work). However, similar durations of juvenile development have been reported for other epiphytic species. Schuster (1985) reported early stages of differentiated thalli of $H$. physodes and Usnea filipendula after 12 and 10 months, respectively and Ott $(1987 d)$ discussed the influence of the microclimate on the developmental rate. Considerably faster developments were obtained in laboratory experiments on Peltigera didactyla, for which Stocker-Wörgötter \& Türk (1989) reported a development of small lobules from soredia within 3 months. For $L$. pulmonaria Hallingbäck (1990) described the development from fragments and soredia of thalli rubbed on the surface of rough tree bark after 10 months. Afterwards, rapid growth led to $12-20 \mathrm{~mm}$ diam. thalli within the next 
6 months, on a tree in semi-open landscape. In this experiment the growth rate of juvenile lobes was significantly lower, the lobes being about $3 \mathrm{~mm}$ wide after 30 months, probably due to limiting light at our study site.

The experiments further demonstrated that the small population size of $L$. pulmonaria on the study site was not due to ecological factors being unfavourable for the juvenile development of $L$. pulmonaria. However, I concluded that the distribution of $L$. pulmonaria within this stand on the Swiss Plateau was clearly limited by its low reproductive potential, which may fail to compete with a relatively high disturbance, natural or anthropogenic, of the stand. Although on the study site the main disturbance was a local wind throw in 1928, changes in forest management (Rose 1992), including shorter cutting cycles (Denison et al. 1977), are probably the main factors that may lead to a rapid disappearance of $L$. pulmonaria and other, especially competitive (Grime 1977; Rogers 1990), lichens.

Given a high extinction probability for small populations (Soulé 1987), protection and conservation of the habitat are not sufficient to maintain a natural epiphytic population that is restricted to a very small number of phorophytes, especially if its reproductive potential is not high enough to colonize a considerable number of additional phorophytes in the near future. Long-term maintenance of small populations could probably be most successfully achieved by increasing the population size in terms of numbers of individuals (Goodman 1987) and subpopulations expressed as the number of phorophytes colonized in an existing mosaic of habitable patches (Gilpin 1987). Transplanting or propagating lichens to previously uncolonized trees is the most promising way if natural dispersal is unsuccessful. However, most of the formerly described methods for transplanting lichens, reviewed by Hallingbäck (1990), need considerable quantities of lichen material, for example one thallus per transplant, which may endanger the natural population by fragmentation.

When transplanting vegetative diaspores the risk of damaging existing populations or individuals is negligible, and therefore the method described is also a suitable approach for future lichen conservation activities for increasing small and therefore endangered populations.

I thank Mrs B. Schneider for carefully sectioning and staining the diaspores for light microscopy, P. Hatvani for assistance at the LTSEM and Mrs M. J. Sieber for correcting the English text. Stimulating discussions with S. Ott, R. Honegger, B. Frey and J. Innes are gratefully acknowledged.

REFERENCES

Ahmadjian, V. (1990) What have synthetic lichens told us about real lichens?. Bibliotheca Lichenologica 38: 3-12.

Ahmadjian, V. (1993) The Lichen Symbiosis. New York: John Wiley.

Armstrong, R. (1990) Dispersal, establishment and survival of soredia and fragments of the lichen, Hypogymnia physodes. New Phytologist 114: 239-245.

Bailey, R. (1976) Ecological aspects of dispersal and establishment in lichens. In Lichenology: Progress and Problems (D. H. Brown, D. L. Hawksworth \& R. H. Bailey, eds): 215-247. London: Academic Press.

Bowler, P. A. \& Rundel, P. W. (1975) Reproductive strategies in lichens. Botanical fournal of the Linnean Society 70: 325-340. 
Büdel, B. \& Scheidegger, C. (1995) Thallus morphology and anatomy. In Lichen Biology (T. H. Nash III, ed): in press. Cambridge: Cambridge University Press.

Clark, G. (1981) Staining procedures, 4th Edn. Baltimore: Williams and Wilkins.

Denison, R., Caldwell, B., Bormann, B., Eldred, L., Swanberg, C. \& Anderson, S. (1977) The effects of acid rain on nitrogen fixation in western Washington coniferous forests. Water, Air and Soil Pollution 8: 21-34.

Denison, W. C. (1988) Culturing the lichen Lobaria oregana and L. pulmonaria on nylon monofilament. Mycologia 80: 811-814.

During, H. J. (1992) Ecological classifications of bryophytes and lichens. In Bryophytes and Lichens in a Changing Environment (J. W. Bates \& A. Farmer, eds): 1-31. Oxford: Clarendon Press.

Echlin, P. (1992) Low-temperature Microscopy and Analysis. New York: Plenum Press.

Garty, J. \& Delarea, J. (1988) Evidence of liberation of lichen ascospores in clusters and reports on contact between free-living algal cells and germinating lichen ascospores under natural conditions. Canadian fournal of Botany 66: 2171-2177.

Gauslaa, Y. (1985) The ecology of Lobarion pulmonariae and Parmelion caperatae in Quercus dominated forests in southern-west Norway. Lichenologist 17: 117-140.

Gilpin, M. E. (1987) Spatial structure and population vulnerability. In Viable Populations for Conservation (M. E. Soulé, ed): 125-139. Cambridge: Cambridge University Press.

Goodman, D. (1987) The demography of change extinction. In Viable Populations for Conservation (M. E. Soulé, ed): 11-34. Cambridge: Cambridge University Press.

Grime, J. P. (1977) Evidence for the existence of three primary strategies in plants and its relevance to ecological and evolutionary theory. The American Naturalist 111: 1169-1194.

Hallingbäck, T. (1990) Transplanting Lobaria pulmonaria to new localities and a review on the transplanting of lichens. Windahlia 18: 57-64.

Hallingbäck, T. \& Martinsson, P.-O. (1987) The retreat of two lichens, Lobaria pulmonaria and L. scrobiculata in the district of Gäsene (SW Sweden). Windahlia 17: 27-32.

Harper, J. L. (1977) Population Biology of Plants. London: Academic Press.

Hawksworth, D. L. (1971) Lobaria pulmonaria (L.) Hoffm. transplanted into Dovedale Derbyshire. Naturalist 1971: 127-128.

Honegger, R. (1987) Isidium formation and the development of juvenile thalli in Parmelia pastillifera (Lecanorales, lichenized Ascomycetes). Botanica Helvetica 97: 147-152.

Jahns, H. M. (1984) Morphology, reproduction and water relations-a system of morphogenetic interactions in Parmelia saxatilis. Beihefte Nova Hedwigia 79: 715-737.

Jahns, H. M. (1988) The lichen thallus. In CRC Handbook of Lichenology, Vol. 1 (M. Galun, ed.): 95-143. Boca Raton: CRC Press.

Jordan, W. P. (1970) The internal cephalodia of the genus Lobaria. Bryologist 73: 669-681.

Jordan, W. P. (1973) The genus Lobaria in North America North of Mexico. Bryologist 76: $225-251$.

Müller, T., Guggenheim, R., Düggelin, M. \& Scheidegger, C. (1991) Freeze-fracturing for conventional and field emission low-temperature scanning electron microscopy: the scanning cryo unit SCU 020. Foumal of Microscopy 161: 73-83.

Naylor, R. E. L. (1985) Establishment and peri-establishment mortality. In Studies on Plant Demography, a Festschrift for fohn L. Harper (J. White, ed.): 95-109. London: Academic Press.

Ott, S. (1987a) Sexual reproduction and developmental adaptations in Xanthoria parietina. Nordic Fournal of Botany 7: 219-228.

Ott, S. (1987b) Reproductive strategies in lichens. In Progress and Problems in Lichenology in the Eighties (E. Peveling, ed.): 81-93. Berlin: J. Cramer

Ott, S. (1987c) The juvenile development of lichen thalli from vegetative diaspores. Symbiosis 3: 57-74.

Ott, S. (1987d) Differences in the developmental rates of lichens. Annales Botanici Fennici 24: 385-393.

van der Pijl, L. (1982) Principles of Dispersal in Higher Plants. 3rd Edn. Berlin: Springer.

Poelt, J. (1993) La riproduzione asessuale nei licheni. Notiziario della Società Lichenologica Italiana 6: $9-28$.

Poelt, J. (1995) On lichenized asexual diaspores in foliose lichens-a contribution towards a more differented nomenclature (Lichens, Lecanorales). Cryptogamic Botany: in press. 
Rogers, R. W. (1990) Ecological strategies in lichens. Lichenologist 22: 149-162.

Rose, F. (1976) Lichenological indicators of age and environmental continuity in woodlands. In Lichenology: Progress and Problems (D. H. Brown, D. L. Hawksworth \& R. H. Bailey, eds): 279-307. London: Academic Press.

Rose, F. (1992) Temperate forest management: its effects on bryophyte and lichen floras and habitats. In Bryophytes and Lichens in a Changing Environment (J. W. Bates \& A. Farmer, eds): 211-233. Oxford: Clarendon Press.

Scheidegger, C. (1994) Low-temperature scanning electron microscopy: the localization of free and perturbed water and its role in the morphology of the lichen symbionts. Cryptogamic Botany 4: 290-299.

Scheidegger, C. \& Schroeter, B. (1995) Effects of ozone fumigation on epiphytic macrolichens: Ultrastructure, $\mathrm{CO}_{2}$-gas exchange and chlorophyll fluorescence. Environmental Pollution 88: 345-354.

Scheidegger, C., Dietrich, M., Frei, M., Keller, C., Kuhn, N. \& Wildi, E. (1991a) Zur Waldflechtenflora des westlichen Aargauer Mittellandes und ihrem Wandel seit 1960. Mitteilungen der Aargauischen Naturforschenden Gesellschaft 33: 175-191.

Scheidegger, C., Günthardt-Goerg, M., Matyssek, R. \& Hatvani, P. (1991b) Low-temperature scanning electron microscopy of birch leaves after exposure to ozone. Fournal of Microscopy 161: $85-95$.

Schuster, G. (1985) Die Jugendentwicklung von Flechten. Bibliotheca Lichenologica 20: 1-206.

Schuster, G., Ott, S. \& Jahns, H. M. (1985) Artificial cultures of lichens in the natural environment. Lichenologist 17: 247-253.

Sigal, L. L. \& Johnston, J. W. (1986) Effects of acid rain and ozone on nitrogen fixation and photosynthesis in the lichen Lobaria pulmonaria (L.) Hoffm. Environmental and Experimental Botany 26: 59-64.

Soulé, M. E. (1987) Viable Populations for Conservation. Cambridge: Cambridge University Press.

Stocker-Wörgötter, E. \& Türk, R. (1989) Artificial cultures of the cyanobacterial lichen Peltigera didactyla (Peltigeraceae) in the natural environment. Plant Systematics and Evolution 165: $39-48$.

Wirth, V. (1976) Veränderung der Fechtenflora und Flechtenvegetation in der Bundesrepublik Deutschland. Schriftenr. Vegetationsk. 10: 177-202.

Wirth, V. (1987) Die Fechten Baden-Württembergs. Stuttgart: Ulmer.

Yoshimura, I. (1971) The genus Lobaria of Eastern Asia. Fournal of the Hattori Botanical Laboratory 34: 231-364. 